\title{
AN UNDERSTANDING OF EARLY MEDIEVAL KASHMIR POLITY
}

\author{
JASLEEN KOUR
}

Ph.D. Scholar History (Net-JRF), University of Jammu, India

\begin{abstract}
The early medieval period, in spite of being a part of the historiography for quite some time now, still continues to be a matter of debate and discussion among the scholars in the circles of history. The need has arisendue the fact that the study of history of regions has gained momentum and this usually leads to applying of the existing nomenclature of ancient, medieval and modern when studying regional histories without giving much thought to the peculiarities of a particular region. The same lacuna is observed in the history of Kashmir valley. While a lot of works are particularly attributed to its early medieval period, the nature of those works is often boxed on the lines of a nationalist approach which makes political history the centre of study without considering the actual reasons that led to the development of political structures. Various material factors must be at play and they must have affected the power dynamics of the region. The paper therefore, focuses on trying to understand the early medieval polity of Kashmir beyond the juxtaposition of a centralized or a decentralized polity by focusing on its regional specificities and how they influenced the distribution of power.
\end{abstract}

KEYWORDS: Early Medieval Period, Political Structures, Regional Specificities

Received: Aug 13, 2020; Accepted: Sep 02, 2020; Published: Sep 21, 2020; Paper Id.: IJHRDEC20203

\section{INTRODUCTION}

The valley of Kashmir has always been an area of interest and curiosity among the scholars all across the globe, the interest peeking more so in the recent times due to the political upheaval that has been going on for quite some time. The beauty of the valley, its strategic location and its historical development were the reasons that attracted the scholars to invest their writings on it. In addition, a romanticism has always been associated with the valley and its scenery, leading to writers and poets churning out larger than life commentaries on the environs and picturesque beauty of Kashmir and many a times hardly going beyond it. This entire spirit of inquisitiveness only increased when Bernier referred to the valley as the "Heaven of Indies" and from then on, various European travellers took it upon themselves to uncover this hidden treasure. Another aspect that one needs to understand with the context of valley is that this place lies in the lap of Himalayas and this factor played a huge role with respect to its association with the Indian subcontinent, China and Central Asia in the early and early medieval times. The fact that Kashmir attracted attention during the British period and subsequent writings were produced on it, in no ways means that Kashmir herself lacked an idea of history and writings in general. Rather, Kashmir was probably the only region in the Sub-continent that possessed a written record of her history in the form of Rajatarangini of Kalhana.So much importance has been held by this single text that it surprised even the European scholars that a text so readily was available that confirmed to their notion of what a historical text should be like. Not only Rajatarangini but various other source materials either in the form of poetry or prose shed ample light on past of the valley and help scholars who are working on reconstructing its history, Kshemendra's works being one of them. Keeping all these aspects in 
mind, it becomes important that one tries to construct and understand how the valley must have been like in the early medieval times and how that period has been perceived by the scholars.

\section{AN IDEA OF EARLY MEDIEVAL KASHMIR}

Early Medieval is one term which has now found its ground in the annals of history and more and more work is being produced on this area of transition from ancient to medieval but that does not always mean that regional writers have always confirmed to this notion. In fact, this term which has now been a part of Indian Historiography for quite some time has still not found a very strong foothold among the scholars who are dealing with regional history of Kashmir and somehow are still stuck with the conventional nomenclatures of either ancient, medieval and modern or Hindu, Muslim and British period. Rather, one would feel that the process of historical change in Kashmir has not been seriously understood by the scholars. Undoubtedly, theses and occasional papers have been produced and are still being produced but on a whole, the idea that there was an early medieval Kashmir is lost in the background of a much-celebrated centralized polity. There is no denying the fact that the period from $7^{\text {th }}$ to $12^{\text {th }}$ centuries, which is often fitted into the ambit of early medieval history, has ample source material for a scholar with respect to Kashmir but all the celebrated works of this region have somehow been stuck with the conventional lines.

To have an idea as to how one needs to deal with an early medieval Kashmir, it is important to understand what this period stands for. A basic understanding would mean that with a certain amount of continuity, this period embodies a series of change and a transition into the medieval period. This would also mean that the Indian society was not a stagnant one and thus challenge the very Colonial perception of a changeless India. Here, one also needs to understand that whatever changes were happening should not be seen in a European light, meaning that since these changes were Indian so they should be understood in an Indian context. Similarly, this applies to any particular region under study. Since every region has its peculiarities, it should not be studied in a pan Indian context. Yes, the basic meaning of the phrase early medieval does remain the same but the historical development and the subsequent changes of every region vary and hence, should be studied individually.

Coming down to Kashmir, the trajectory of its early medieval period as mentioned above does show variations with respect to the early medieval India. The debate of an early medieval India often finds itself embroidered with the idea of a "Feudal India", whether it happened or not or was India as feudal as it is often understood to be is a matter of agreement and disagreement but Kashmir on the other hand, shows distinctive and individualistic features of its own in the form of a centralized polity and a very strong one at that was functioning in Kashmir in the early medieval period. So now the question arises that if the early medieval period is a series of changes in which the centralized polity of India (the strong centralization seen in north India) shifts towards a decentralized structure, emergence of landed intermediaries and a feeling of surrender to the lord, then how does one say that there existed in the early medieval period in Kashmir? The answer to this lies in the simple understanding that even if there was a centralized polity functioning in the valley, the material aspect was still at play. Meaning that a centralized political structure was not just about a political administration and polity, there must have been various factors that would have led to the emergence of this political structure and these factors were not only centred around polity and power, rather, socio-economic activities must have induced these political changes. If one has to sum up in simpler terms, one needs to go beyond the traditional centralized and decentralized polity and understand the growth of various institutions from the point of view of regional specificities. 
However, when we studies the polity of Kashmir, there is an absence of references regarding the regional specificities in the works of writers and the material is often times boxed into the category of a national model of writing, often times even a colonial model, fitting dynastic rule at the centre and playing around its elements. Here, the study of emergence of political structures is hardly played with. It seems that Rajatarangini of Kalhana is seen only through a peeping hole of dynastic history and a picture created with strong king at the centre and people under him, without an understanding of the role played by the intermediaries if there were any. But, the same Rajatarangini mentions about the land grants and somehow, still those are not sufficient to conclude that Kashmir experienced an early medieval period dominated by landed barons because that seems truly out of question.Because in case of Kashmir, the idea of an Agraharais not plain simple and there have been instances when the granted land has been taken back by the king, highlighting the strong hold of the monarchy in contrast of what was happening in Indian Subcontinent. While idea of land grants put together with the emergence of a "feudal India" became the mainstay of early medieval debate in the historical circles, such theme is seen pretty much absent in case of Kashmir. Although, D.D.Kosambi has very clearly pointed out that their existed a feudalism in Kashmir, again that does not in any way means that general structure of a feudal setup can be applied here in the valley. But, this also enforces the fact that change was happening in the valley and whatever maybe the cause of change, it did affect the political developments.

\section{FEATURES OF EARLY MEDIEVAL KASHMIR}

The political history of early medieval Kashmir is kind of an escape for the lovers of a strong centralized administration, a king at the helm of the functioning of a monarchical state. This was not the case in north India and often historians point out the lack of a unified central authority. Seeing that a strong monarchy operated in Kashmir provides relief to various scholars so much so that the writings on the valley hardly go beyond its strong political setup. Whatever, regional works have been produced, they boost of rise and growth of dynastic rule and even at times glorifying monarchs such as Lalitaditiya for their tremendous expansionist policies and very rightly so. But, the idea of a strong political setup, judicial system, governance, etc. was not the only aspect of the early medieval Kashmir polity. The idea that trade and commerce, in spite of its difficult terrain, was very much a part of the history of valley needs to be paid way more focus onbecause the items of trade were strongly deciding the lifestyle of the people of the region. The constant trade of salt and saffron was a distinctive feature of the valley and also shunned the usually accepted fact that valley was aloof and inaccessible. It might have been inaccessible in the ancient times, obviously owing to its geographical conditions and Kalhana does point this out when he goes on to say that valley could not be destroyed by the enemy but the situation seems to be different during the early medieval period. Therefore, while constructing the political setup, one needs to pay full attention to what were the material conditions exactly as they were providing a base for any kind of political structure. For example, the import of goods like salt, metals, led to the concentration of wealth in the hands of a few, who started to acquire surplus by these trading activities and started to maintain arms as well, turning to the Damaras. So, this aspect of the early medieval Kashmir cannot be ignored. Often times, writers and scholars have just mentioned altercations among the ruling class and the Damaras without getting into the details of this class actually became powerful. One needs to understand that just like the landed intermediaries of India, this class was of land barons in Kashmir who played a very strong role in the power structure of the valley.

Furthermore, the idea of the Agrahara land given to the Brahmans here in the valley did not only havea theological aspect, rather it seems to a power dynamic between the king and the Damaras, for certain instances show that 
king at times of a conflict with the Damara would confiscate the land which was donated to maintain thecost of his forces. Thus, highlighting that the grants given in Kashmir had a different connotation as compared to the ones bestowed in other parts of the Indian Subcontinent. Another important factor that needs to be understood while studying the early medieval polity is the importance of irrigation. Kashmir is a land governed to a great extent by water bodies, its very origin being associated with a lake. So, the water did play a strong role in the trade and navigation of goods was more or less controlled by the royal authority and ample examples of kings and their ministers building embankments and protecting the water channel are available. This again is a peculiar feature of Kashmir polity governed obviously by its geography.

\section{CONCLUSIONS}

While reading history, one cannot only be interested in political history or social or economic history because leaving one of these or studying one of these in isolation would mean that a considerable chunk of our past would remain hidden in the shadows. What really is important is to understand that history is an interplay of all these aspects and interestingly the early medieval period provides an opportunity to experiment with these. Also, reading just political history would mean that we are reading power relation without any understanding of the greater forces which are at play, like the material and social changes. Therefore, while uncovering the early medieval polity of the Kashmir, one needs to not delimit to just polity. D.D. Kosambi in this regard has provided a base when he discusses "Origins of Feudalism in Kashmir", but again can we really box the early medieval period into just feudalism based on the issuance of just some land grants and trading activities? Because, as mentioned above, the nature of land grants in Kashmir was different. Also, this paves way for more and more understanding of the regional specificities and understanding early medieval period by placing it in a regional context. However, when looks at the works on polity of the valley, they are mostly on the lines of a nationalist structure and provide a lacuna towards the understanding of the power dynamic in the region. The idea of a monarchical state, dominated by a worthy king functioning in a centralized administration is the more dominant theme. It is more of a hangover of the nationalist historiography. Although in recent times, scholars have naturally drifted towards early medieval period and are trying to understand the peculiarities of the region, yet the interdependence of socio-economic and political factor is often sidelined.

With the coming of the Muslim rule, the Jagirsbecame common but how far this was the continuation of the feudal model needs to be analysed and what exactly was the condition of land in the valley need to be addressed much more. Also, Kashmir was and continues to be the most fascinating aspect of research and the idea that this land possessed a rich history and has shown a cultural growth over centuries needs to paid more attention to rather than just categorizing it as a disturbed region.

\section{REFERENCES}

1. B.D.Chattopadhyaya, The Making of Early Medieval India, New Delhi: OUP, 1994.

2. D.D. Kosambi, Origins of Feudalism in Kashmir, Journal of Royal Branch of Bombay Asiatic Society, Bombay, 1965.

3. H.H. Wilson, Hindu History of Kashmir, Calcutta, 1960.

4. LIYAKAT, MUJEEB. "UNDERSTANDING WEB 2.0: THE EXTENSIONS OF EMOTIONAL RELEASE AND STATUS: USES AND GRATIFICATION THEORY IN THE CONTEXT OF KASHMIR."International Journal of Communication and Media Studies (IJCMS) 7. 4, Oct 2017, 21-28 
5. Kalahana, Rajatarangini, A Chronicle of the kings of Kashmir, English translation with an introduction commentary and appendices by M.A.Stein, three vols., MotilalBanarasidass, Delhi, 1961.

6. M.A. Stein, The Ancient Geography of Kashmir, Journal of the Asiatic Society ofBengal, Part-1Extra No. -11899, Indological Book corporation, Patna, 1977.

7. SABA, NEELAM, and N. K. Tripathi. "Preliminary cytogenetic investigation of Euphlyctiscyanophlyctis (Anura, Amphibia) from Jammu and Kashmir, India." Int. Journal of Zool. and Research 3.3 (2013): 29-36.

8. Nila, The NilamataPurana, vol.2, A critical edition and English translation by V. Kumari, J\&K Academy of Art, Culture and Languages, Srinagar, 1973.

9. P.N.K Bamazi, A History of Kashmir, Life and Light Publishers, 1962.

10. Kashmir and Central Asia, Life and Light Publishers, Delhi, 1980.

11. Culture and Political History of Kashmir, Vol. 1, Gulshan Books, Srinagar, 2007.

12. RomillaThapar, A History of India, Vol. I, Penguin, 1966.

13. R.S. Sharma, Perspectives in Economic and Social History of Early India, New Delhi: MunshiramManoharlal, 1983.

14. Raj, S., S. U. N. I. T. A. Sharma, and V. Singh. "An Overview of the Problem faced by the Migrant Kashmiri Pandits in Jammu district and Possible Solutions." International Journal of Research in Humanities, Arts and Literature 2 (2014): 71-86.

15. Aspects of Political Ideas and Institutions in Ancient India, MotilalBanarsidass, Delhi, 1959.

16. VedKumari, TheNilamataPurana Vol.1 (A Cultural and Literary Study of a Kashmiri Purana, J\&K Academy of Art, Culture and Languages, Srinagar, 1988.

17. ITOO, MUSHTAQ AHMAD, and FAROOQ AHMAD RATHER. "Tourism of Nineties: A case study of Kashmir Valley." IMPACT: International Journal of research in Arts and literature 2.4 (2014): 109-112.

18. W.R.Lawarence, The Valley of Kashmir, Reprint Kesar Publishers, Srinagar, 1967. 

